\title{
PENGARUH PEMASARAN INTERNAL TERHADAP KEPUASAN PELANGGAN INTERNAL PERUSAHAAN PADA PDAM TIRTA MAYANG KOTA JAMBI
}

\author{
Laila Farhat ${ }^{1}$, Usdeldi ${ }^{2}$
}

\begin{abstract}
This study aimed is to analyze the effect of Internal Marketing to Internal Customer Satisfaction Company On PDAM TirtaMayang city of Jambi, The population is PDAM TirtaMayang Employees, it is selected randomly as many as 72 people. Results were statistically demonstrated that the Internal Marketing consists of five dimensions together affect the internal customer satisfaction on PDAM TirtaMayang determinant coefficient Jambi with 61.00 percent. Partially there are two variables: the recruitment and empowerment of the five dimensions that have a positive and significant effect, while for the other three variables, is not significant. And the most influential variable is the variable employee empowerment. In addition, given the influence of the independent variables together against internal customer satisfaction on the company PDAM TirtaMayang Jambi City by 61.00 percent, 39.00 percent of course there are still other variables beyond the variables that affect the company's internal customer satisfaction on the taps TirtaMayang Jambi City that need to be investigated further.
\end{abstract}

Keywords: Internal Marketing, Internal Customer Satisfaction.

\section{PENDAHULUAN}

Pelayanan yang berkualitas padaeerusahaan penyedia air bersih sangat erat kaitannya dengan performa sumber daya manusia. Pada perusahaan, karyawan adalah pihak yang menyampaikan jasa secara langsung kepada pelanggan. Persepsi pelanggan terhadap kualitas pelayanan, kepuasan pelanggan, dan keputusan untuk tetap menggunakan jasa/produk penyedia layanan sangat dipengaruhi oleh karyawan (Ribhan2010). Oleh karena itu, sangat penting bagi Perusahaan untuk memfasilitasi karyawan sehingga dapat memberikan performa terbaik.

Karyawan merupakan ujung tombak perusahaan, karena mereka berinteraksi langsung dengan pelanggan eksternal, dan secara signifikan menentukan kepuasan pelanggan. Karyawan juga mempengaruhi kredibilitas perusahaan karena selain berperan sebagai penyaji jasa, mereka juga mempengaruhi persepsi pelanggan atau konsumennya. Image baik yang diberikan karyawan sangat penting bagi keberhasilan organisasi.

Karyawan juga merupakan pelanggan pertama dari sebuah perusahaan. Bagaimana perusahaan harus memuaskan karyawan, memperhatikan kebutuhan, keinginan serta harapan, demikian pula tentang kesejahteraan karyawan, semua itu adalah hak yang harus di penuhi oleh perusahaan. Karena kewajiban perusahaan harus memperhatikan kesejahteraan karyawan seperti gaji, tunjangan hari tua, pengembangan karier dan lain-lain agar karyawan puas dengan pekerjaan mereka (Supriyanto dan Ernaway, 2010).

(Kottler, 2009) juga menyebutkan bahwa tidak logis untuk mengharapkan layanan yang sempurna dari sebuah perusahaan, yang karyawannya belum siap

\footnotetext{
${ }^{1}$ Sekolah Tinggi Ilmu Ekonomi Jambi

${ }^{2}$ Sekolah Tinggi Ilmu Ekonomi Jambi
}

Pengaruh Pemasaran Internal terhadap Kepuasan Pelanggan Internal Perusahaan pada PDAM Tirta Mayang Kota Jambi 
untuk menyediakan layanan tersebut. Pemasaran Internal adalah cara untuk mencapai hal itu. Selain itu (Kottler, 2010) demikian jauh mengatakan bahwa jika perusahaan benar-benar ingin memuaskan pelanggannya, karyawanlah yang harus di nomorsatukan bukan pelanggannya.

PDAM Tirta Mayang Kota Jambi merupakan Perusahaan yang bergerak di bidang jasa penyediaan air bersih. Salah satu tujuan di bentuknya PDAM adalah untuk mencukupi kebutuhan masyarakat akan air bersih, meliputi penyediaan, pengembangan pelayanan masyarakatakan air bersih. Dalam rangka mencapai pelayanan pemasaran yang prima, di perlukan performa kinerja karyawan antar lini di Internal PDAM itu sendiri, sebagai penentu strategi untuk mewujudkan sasaran kerja yang di tentukan oleh Manajemen.

Hasil capaian yang diperoleh juga cukup besar, tidak hanya dari sisi keuntungan namun juga layanan terhadap konsumen. Dari hasil kinerja tersebut jumlah pelanggan PDAM Tirta Mayang sendiri telah mencapai diatas 62.883 pelanggan. Dan hal ini dapat disimpulkan bahwa setiap tahun cakupan pelayanan PDAM Tirta Mayang Kota Jambi mengalami kenaikan, rata rata pertumbuhan peningkatannya yaitu 4,17 \%, namun kenaikan tersebut belum dapat mencapai target yang ditetapkan, saat ini cakupan layanan PDAM baru mampu merecover layanan hinga 56,29 persen dari jumlah penduduk Kota Jambi (Laporan Tahunan, 2016).

Cakupan pelayanan (coverage) PDAM Tirta Mayang baru mencapai 56,29 persen atau kisaran 299.881 orang/jiwa penduduk yang terlayani dari total jumlah penduduk Kota Jambi yang berjumlah 681.862 jiwa. Dengan jumlah pelanggan 62.883.(Laporan Tahnan, 2015).

Tujuan Internal Marketing adalah untuk memotivasi karyawan sehingga karyawan dapat memberikan potensi terbaiknya bagi perusahaan. Menurut Fisk dkk. (1993) ada dua isu utama dalam intern pemasaran. Pertama, gagasan karyawan sebagai pelanggan internal dan kedua, kebutuhan organisasi untuk memenuhi pelanggan internal sehingga dia siap memberikan pelayanan yang terbaik pada pelanggan eksternal. Meskipun pemasaran eksternal tetap yang paling penting guna pengembangan usaha, namun memberikan kepuasan kepada Pelanggan Internal (karyawan) juga penting. Ketika karyawan memahami dan berkomitmen untuk memajukan perusahaan, pemasaran eksternal menjadi lebih efektif. Internal marketing merupakan sarana yang melibatkan karyawan disemua tingkatan dalam program pemasaran, memungkinkan bagi karyawan untuk memahami peran mereka dalam proses pemasaran.

Pemasaran Internal (Internal Marketing/IM) merupakan pendekatan yang relatif baru yang diadopsi oleh perusahaan dalam rangka meningkatkan kualitas produk dan layanan dalam mencapai tingkatan kinerja yang lebih baik. Perusahaan melihat kegiatan operasi internal merupakan hal yang penting, terutama pemahaman tentang sumber daya manusia perusahaan. Menurut EL Samen dan Alshurideh (2012) menyatakan bahwa sebuah perubahan dengan pola pikir baru telah muncul dengan perusahaan yang kualitas untuk memastikan keberhasilan bisnis.

Menurut Susana (2012) bahwa pelanggan internal merupakan individu departemen lain dalam organisasi yang dilayani oleh pemasok internal. Hal tersebut menunjukkan bahwa suatu organisasi terdiri dari rantai unit individu, yang dihubungkan bersama-sama, selanjutnya unit terkait digunakan untuk memuaskan pelanggan eksternal. Bersamaan dengan hal tersebut kesadaran

Pengaruh Pemasaran Internal terhadap Kepuasan Pelanggan Internal Perusahaan pada PDAM Tirta Mayang Kota Jambi 
pelanggan baik ekternal maupun internal terhadap kualitas merupakan hal terpenting, pada kondisi tersebut organisasi dituntut untuk meningkatkan segala aspek kualitas.

Menurut Lombard (2010) menjelaskan bahwa keberhasilan penerapan prinsip-prinsip pemasaran internal (internal marketing) merupakan prasyarat untuk pemasaran eksternal yang efektf. Kegiatan pemasaran selalu berujung kepada usaha dalam memberikan kepuasan pelanggan (Jumadi 2012). Perusahaan mempunyai dua pelanggan yaitu pelanggan internal (karyawan) dan pelanggan eksternal (konsumen) yang senantiasa harus mendapat perhatian dan pelayanan yang baik. Penilaian program pemasaran internal (internal marketing, digunakan untuk mengetahui pandangan karyawan (pelanggan internal) terhadap perlakuan perusahaan yang mereka terima. Upaya ini membantu manajer untuk menemukan apa saja yang perlu perbaikan untuk dianalisis lebih lanjut. Beberapa penelitian yang terkait dengan pemasaran internal antara lain, penelitian yang dilakukan oleh Hers (2010) yang menyatakan bahwa kepuasan pelanggan eksternal dapat dicapai melalui kepuasan pelanggan internal. Aburoub dan Hers (2011) yang menjelaskan dalam penelitiannya bahwa internal marketing mempunyai pengaruh positif terhadap kinerja perusahaan, demikian juga dengan Eldeen dan El-Said (2011) yang menyimpulkan bahwa organisasi telah menerapkan internal marketing dengan baik dan berdampak terhadap perusahaan.

Hasil penelitian EL Samen and Alshurideh (2012) yang menggunakan dimensi pemasaran internal (internal marketing) dan dimensi kualitas layanan internal, (internal quality service) diperoleh kesimpulan bahwa ada hubungan antara dimensi internal marketing dengan dimensi kualitas layanan internal (internal quality service). Hal ini juga didukung oleh hasil penelitian dari Wangetal. (2012) yang menyatakan bahwa internal marketing yang mencakup efektifitas kegiatan pelatihan terhadap karyawan berpengaruh terhadap kepuasan pelanggan.

Untuk mendukung hal tersebut perlu adanya pendekatan Pemasaran Internal yang di terapkan pada PDAM Tirta Mayang. (Kottler, 2009) menyatakan bahwa pemasaran internal merupakan tugas untuk merektrut, melatih dan memotivasi karyawan yang mampu untuk melayani pelanggan dengan baik.

\section{Subjek dan Objek Penelitian}

\section{METODOLOGI PENELITIAN}

Subjek penelitian adalah subjek yang dituju oleh peneliti (Arikunto, 2006). Subjek penelitian yang diambil dalam penelitian ini adalah karyawan di PDAM Tirta Mayang Kota Jambi. Objek penelitian adalah sesuatu yang menjadi pemusatan pada kegiatan penelitian, atau dengan kata lain segala sesuatu yang menjadi sasaran penelitian, sehingga objek penelitian ini adalah variabel-variabel yang akan diuji yaitu variabel independen atau variabel bebas dan variabel dependen atau variabel terikat (Sugiyono, 2002). Dalam penelitian ini variabel independen yang akan diuji adalah internal marketing dengan dimensi komunikasi internal, penerimaan karyawan, training/pengembangan, pemberdayaan dan kompensasi. Sedangkan variabel dependennya adalah Kepuasan Karyawan dengan dimensipekerjaan itu sendiri, gaji, kesempatan promosi, pengawasan, dan rekan kerja. 


\section{Sampel Penelitian}

Jumlah sampel penelitian ini adalah karyawan di PDAM TirtaMayang Kota Jambisebanyak72 (tujuhpuluhdua) orang.

\section{Metode Analisis Data}

Analisis data yang digunakan adalah analisis regresi linier berganda dengan menggunakan bantuan komputer melalui software SPSS 20.00 For windows. berikut:

Persamaan statistik yang digunakan dalam peneitian ini di uraikan sebagai

$$
Y=\alpha+b_{1} X_{1}+b_{2} X_{2}+b_{3} X_{3}+b_{4} X_{4}+b_{5} X_{5}+e
$$

Dimana :

$\mathrm{Y} \quad=$ Kepuasan Pelanggan Internal.

$\alpha=$ Intercept $/$ Konstanta

$\mathrm{b}_{1} \mathrm{~b}_{5}=$ Koefisien regresi

$\mathrm{X}_{1} \quad=$ Komunikasi Internal

$\mathrm{X}_{2} \quad=$ Penerimaan Karyawan

$\mathrm{X}_{3} \quad=$ Training/Pengembangan

$\mathrm{X}_{4} \quad=$ Pemberdayaan

$\mathrm{X}_{5} \quad=$ Kompensasi

$\mathrm{e} \quad=$ Error

\section{Uji Validitas Data}

Uji validitas dilakukan untuk mengetahui apakah alat ukur yang telah disusun dapat digunakan untuk mengukur apa yang hendak diukur secara tepat (Indiantoro, 2002). Sebuah instrumen dikatakan valid apabila dapat mengungkapakan data dari variabel yang diteliti secara tepat dan mempunyai validitas tinggi, tinggi rendahnya validitas instrumen menunjukkan sejauh mana data yang terkumpul tidak menyimpang dari gambaran tentang variabel yang dimaksud (Indiantoro, 2002). Untuk menguji validitas dapat dihitung korelasi antara masing-masing pernyataan skor total dengan teknik korelasi "product moment" dari pearson (Ghozali, 2009).

\section{Uji Reliabilitas Data}

Uji reliabilitas yaitu uji yang digunakan untuk mengukur kuesioner yang merupakan indikator dari variabel. Pengukuran dilakukan hanya sekali dan kemudian hasilnya dibandingkan dengan pertanyaan. Pengujian reliabilitas dilakukan untuk mengetahui sejauh mana suatu instrument dapat memberikan hasil pengukuran yang konsisten. Pengujian reliabilitas dilakukan dengan menggunakan Uji Alpha Cronbach.

Perhitungan bobot penilaian kuesioner adalah dengan menggunakan skala Likert yang merupakan metode yang digunakan untuk mengukur sikap dengan menyatakan setuju atau ketidaksetujuannya terhadap subjek, objek atau kejadian tertentu (Indriantoro, 2002). Skala Likert berisi lima tingkatan jawaban dengan pilihan sebagai berikut. 


\begin{tabular}{ll}
\multicolumn{2}{c}{ Tabel 1.Skala Likert } \\
\hline Tingkat Setuju & Skor \\
\hline Sangat Tidak Setuju & 1 \\
Tidak Setuju & 2 \\
Netral & 3 \\
Setuju & 4 \\
Sangat Setuju & 5 \\
\hline
\end{tabular}

\section{Uji Asumsi Klasik}

Model regresi berganda yang di gunakan dalam pengujian hipotesis dikatakan model yang baik apabila model tersebut memenuhi normalitas data dan terbebas dari asumsi klasik, yaitu normalitas, multikolinearitas, autokorelasi dan heteroskedastisitas (Ghozali, 2002). Dalam Penelitian ini, asumsi klasik autokorelasi tidak di uji dengan alasan data yang dikumpulkan dan di olah merupakan data cross section, sedangkan masalah autokorelasi sering terjadi pada data time series. Uji asumsi klasik yang digunakan meliputi uji normalitas, uji multikolinearitas dan uji heterosdastisitas.

\section{Uji Regresi Berganda}

Metode regresi berganda ini dikembangkan untuk mengestimasi nilai variabel dependen (Y) dengan menggunakan lebih dari satu variabel independen $(\mathrm{X})$. Adapun persamaan regresinya adalah sebagai berikut:

$$
Y=\alpha+b_{1} X_{1}+b_{2} X_{2}+b_{3} X_{3}+b_{4} X_{4}+b_{5} X_{5}+e
$$

Dimana :

$\mathrm{Y} \quad=$ Kepuasan Pelanggan Internal.

$\alpha=$ Intercept $/$ Konstanta

$\mathrm{b}_{1} \mathrm{~b}_{5}=$ Koefisien regresi

$\mathrm{X}_{1} \quad=$ Komunikasi Internal

$\mathrm{X}_{2} \quad=$ Penerimaan Karyawan

$\mathrm{X}_{3} \quad=$ Training/Pengembangan

$\mathrm{X}_{4} \quad=$ Pemberdayaan

$\mathrm{X}_{5} \quad=$ Kompensasi

$\mathrm{E} \quad=$ Error

Uji signifikansi parsial dilakukan untuk menguji pengaruh variabel independen terhadap variabel dependen secara parsial. Untuk melakukan uji signifikansi parameter individual digunakan uji t. Untuk dapat memutuskan apakah variabel independen berpengaruh signifikan atau tidak terhadap variabel dependen dilakukan dengan menganalisis nilai signifikansi yang dihasilkan dari output SPSS Versi 20.

Uji signifikansi pengaruh simultan dilakukan untuk mengetahui pengaruh variabel-variabel independen secara simultan terhadap variabel dependen. Untuk pengaruh variabel independen secara simultan digunakan Uji Anova (uji F).

\section{Uji Validitas Data}

\section{HASIL DAN PEMBAHASAN}

Berdasarkan hasil uji validitas yang dilakukan dengan bantuan program SPSS versi 20. menunjukkan bahwa koefisien korelasi Pearson Moment untuk setiap item butir pernyataan dengan skor total variabel pada tingkat signifikansi 0,05 berada dibawah $\mathrm{r}$ tabel sebesar 0,231 . Sehingga dapat diinterpretasikan 
bahwa setiap item indikator instrumen untuk akuntabilitas pengelolaan tersebut adalah valid.

\section{Uji Reliabilitas Data}

Pengujian reliabilitas dilakukan untuk mengetahui sejauh mana suatu instrumen dapat memberikan hasil pengukuran yang konsisten. Pengujian reliabilitas dilakukan dengan menggunakan Uji Alpha Cronbach

Berdasarkan hasil pengujian reabilitas yang terlihat pada tabel di atas, maka diketahui bahwa kuesioner yang digunakan memiliki nilai koefisien alpha lebih besar dari 0.60 sehingga dapat disimpulkan bahwa kuesioner di dalam penelitian ini dinyatakan reliabel.

\section{Uji Normalitas}

Hasil uji normalitas dengan grafik probability plot dapat dilihat pada gambar di bawah ini.

Gambar 1. Hasil Uji Normalitas

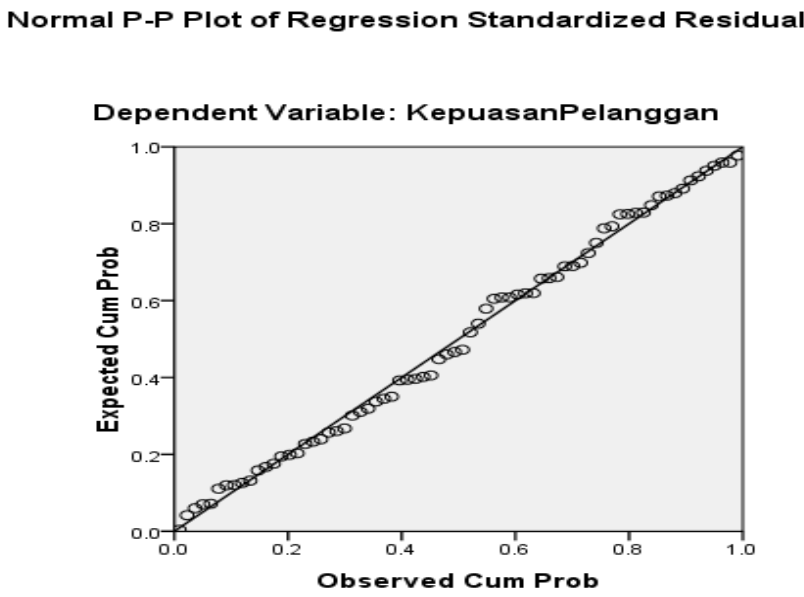

Berdasarkan gambar di atas, dapat dilihat bahwa data menyebar disekitar garis diagonal dan mengikuti garis diagonal. Dengan demikian model regresi yang digunakan memenuh asumsi normalitas

\section{Uji Multikolinieritas}

Untuk mendeteksi ada atau tidaknya multikolinieritas yang tinggi antar variabel independen dapat deteksi dengan cara melihat nilai tolerance dan variance inflaction factor (VIF). Nilai cutoff yang dipakai untuk menunjukkan tidak terjadi multikolinieritas adalah nilai tolerance di atas 0,10 atau nilai VIF di bawah 10 .

Tabel 2. Hasil Uji Multikolinieritas

\begin{tabular}{|c|c|c|}
\hline \multicolumn{3}{|c|}{ Coefficients* } \\
\hline \multirow{2}{*}{ Model } & \multicolumn{2}{|c|}{ Collinierity Statistic } \\
\hline & Tolerance & VIF \\
\hline Komunikasi internal & 0,677 & 1,476 \\
\hline Penerimaan karyawan & 0,611 & 1,636 \\
\hline Training/Pengembangan & 0,582 & 1,717 \\
\hline Pemberdayaan & 0,557 & 1,796 \\
\hline Kompensasi & 0,574 & 1,744 \\
\hline
\end{tabular}


Pada tabel terlihat bahwa semua variabel independen memperoleh angka VIF ada disekitar 1 serta nilai tolerance mendekati 1, sehingga dapat disimpulkan model regresi tidak terdapat masalah multikolinieritas.

\section{Uji Heteroskedastisitas}

Salah satu cara untuk mengetahui ada tidaknya heteroskadasitas dalam satu model regresi linier berganda adalah dengan melihat grafik scatterplot atau nilai prediksi variabel terikat yaitu SRESID dengan residual error yaitu ZPRED. Uji ini dilakukan dengan memperhatikan pola penyebaan tititk-titik. Gambar 5.12 akan memperlihatkan pola-pola penyebaran titik.

Gambar 2. Uji Heteroskedasitas

Scatterplot

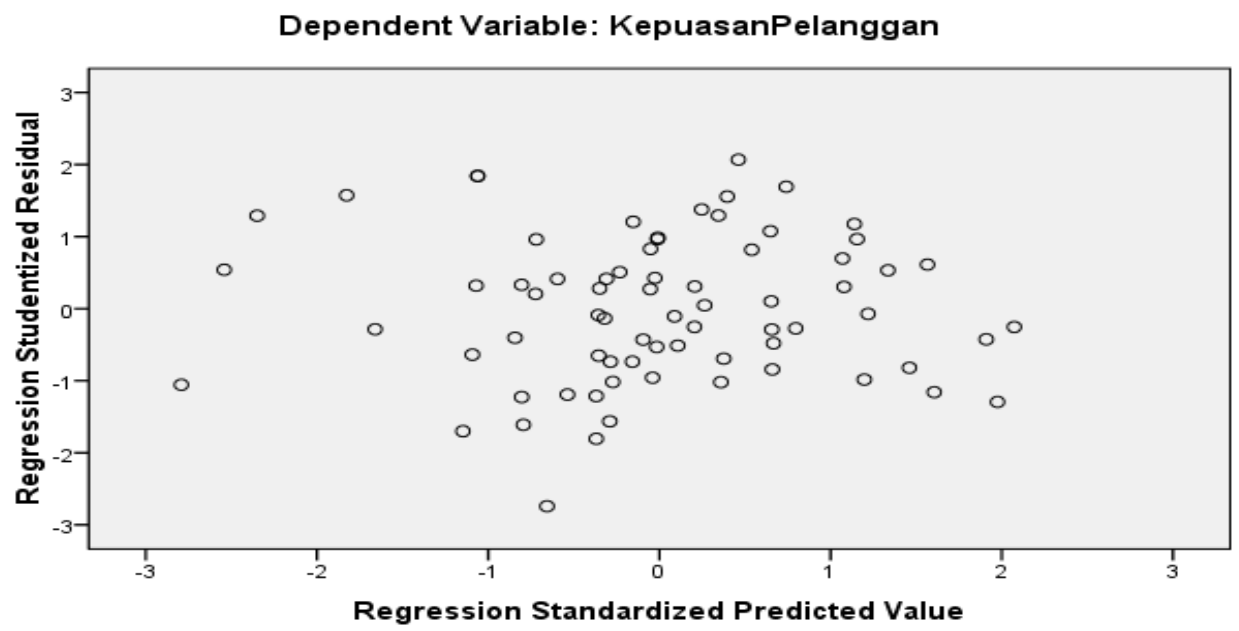

Grafik scatterplot memperlihatkan penyebaran titik-titik yang tidak merata. Titik-titik menyebar kearah atas maupun bawah angka 0 pada sumbu Y. Pola penyebaran titik-titik ini memberikan suatu kesimpulan bahwa tidak terjadi heteroskedasitas pada model regresi.

\section{Uji Koefisien Determinasi}

Koefesien determinan di gunakan untuk mengetahui keeratan hubungan antara variabel bebas dengan variabel terikat, nilai $\mathrm{R}^{2}$ terletak antara 0 sampai dengan $1\left(0 \leq \mathrm{R}^{2} \leq 1\right)$, Tabel berikut ini akan menunjukkan seberapa besar koefisien determinan yang dihasilkan.

Tabel 3. Hasil Perhitungan Korelasi

Model Summary ${ }^{b}$

\begin{tabular}{|c|c|c|c|c|c|}
\hline \multirow[b]{2}{*}{ Model } & \multirow[b]{2}{*}{$\mathrm{R}$} & \multirow[b]{2}{*}{ R Square } & \multirow{2}{*}{$\begin{array}{l}\text { Adjusted } \\
\text { Square }\end{array}$} & \multicolumn{2}{|c|}{ R Std. Error of the Durbin- } \\
\hline & & & & Estimate & Watson \\
\hline 1 & $.799^{a}$ & .638 & .610 & 5.41667 & 1.871 \\
\hline
\end{tabular}

a. Predictors: (Constant), Kompensasi, Komunikasi, Training, Penerimaan, Pemberdayaan

b. Dependent Variable: KepuasanPelanggan 
Nilai R menerangakan tingkat hubungan antar variabel-variabel independen (X) dengan variabel dependen (Y), pada tabel di atas dapat dilihat bahwa nilai $\mathrm{R}$ sebesar 0,799 atau 79,90\% artinya hubungan antara variabel independen terhadap variabel dependen tergolong kuat.

\section{Uji Parsial (Uji T)}

Pengujian pengaruh parsial atau pengujian hipotesis penelitian dilakukan dengan menganalisis nilai t hitung atau nilai signifikansinya dengan kriteria sebagai berikut:

a. Jika nilai $t$ hitung $>\mathrm{t}$ tabel pada $\mathrm{df} 0,05$ atau nilai signifikansi $<0,05$ maka dapat disimpulkan bahwa variabel independen terbukti secara statistik berpengaruh positif terhadap variabel dependen.

b. Jika nilai t hitung $<\mathrm{t}$ tabel pada df 0,05 atau nilai signifikansi $>0,05$ maka dapat disimpulkan bahwa variabel independen tidak terbukti secara statistik berpengaruh positif terhadap variabel dependen.

Coefficients $^{\mathbf{a}}$

Tabel 4.Hasil Uji Regresi Berganda

\begin{tabular}{|c|c|c|c|c|c|c|c|c|}
\hline \multirow[b]{2}{*}{ Model } & \multicolumn{2}{|c|}{$\begin{array}{l}\text { Unstandardized } \\
\text { Coefficients }\end{array}$} & \multicolumn{3}{|c|}{$\begin{array}{l}\text { Standardized } \\
\text { Coefficients }\end{array}$} & \multicolumn{3}{|c|}{ Correlations } \\
\hline & B & Std. Error & Beta & $\mathrm{t}$ & Sig. & $\begin{array}{l}\text { Zero- } \\
\text { order }\end{array}$ & Partial & Part \\
\hline 1 (Constant) & 28.195 & 6.379 & & 4.420 & .000 & & & \\
\hline Komunikasi & -.047 & .444 & -.010 & -.107 & .915 & .389 & -.013 & -.008 \\
\hline Penerimaan & 1.231 & .345 & .338 & 3.571 & .001 & .648 & .402 & .265 \\
\hline Training & -.037 & .312 & -.011 & -.119 & .906 & .479 & -.015 & -.009 \\
\hline Pemberdayaan & 1.553 & .329 & .471 & 4.724 & .000 & .710 & .503 & .350 \\
\hline Kompensasi & .512 & .315 & .159 & 1.626 & .109 & .587 & .196 & .120 \\
\hline
\end{tabular}

a.Dependent_Variable:

KepuasanPelanggan

Berdasarkan tabel diatas maka persaman regresi yang digunakan sebagai berikut

$$
\mathrm{Y}=28.195-0,047 \mathrm{X}_{1}+1,231 \mathrm{X}_{2}-0,037 \mathrm{X}_{3}+1,553 \mathrm{X}_{4}+0,512 \mathrm{X}_{5}+\mathrm{e}
$$

Dari persamaan garis regresi diatas dapat dijelaskan beberapa hal yaitu :

a. Nilai konstanta (intercept) menunjukkan angka positif sebesar 28.195 artinya kepuasan pelanggan internal pada PDAM Tirta Mayang Kota Jambi akan memiliki kecenderungan bergerak kearah positif dan tinggi, meskipun tanpa ada pengaruh dari dimensi dari pemasaran internal.

b. Koefisien regresi dari dimensi Komunikasi Internal $\left(\mathrm{X}_{1}\right)$.

Koefisien regresi Komunikasi internal menunjukkan angka negative -0,047 yang berarti dengan penambahan satu satuan dimensi komunikasi internal akan terjadi penurunan terhadap kepuasan pelanggan internal pada PDAM Tirta Mayang Kota Jambi sebesar $-0,047 \%$.

c. Koefisien regresi dari dimensi Penerimaan Karyawan $\left(\mathrm{X}_{2}\right)$.

Koefisien regresi Penerimaan Karyawan menunjukkan angka positif 1,231 yang berarti dengan penambahan satu satuan dimensi Penerimaan karyawan akan terjadi peningkatan terhadap kepuasan pelanggan internal pada PDAM Tirta Mayang Kota Jambi sebesar 1,231\%. 
d. Koefisien regresi dari dimensi Training/Pengembangan $\left(\mathrm{X}_{3}\right)$.

Koefisien regresi Training/Pengembangan menunjukkan angka negatif -0,037 yang berarti dengan penambahan satua satuan dimensi Training/Pengembangan akan terjadi penurunan terhadap kepuasan pelanggan internal pada PDAM Tirta Mayang Kota Jambi sebesar - $0,037 \%$.

e. Koefisien regresi dari dimensi Pemberdayaan $\left(\mathrm{X}_{4}\right)$.

Koefisien regresi Pemberdayaan menunjukkan angka positif 1,553 yang berarti dengan penambahan satu satuan dimensi pemberdayaan akan terjadi peningkatan terhadap kepuasan pelanggan internal pada PDAM Tirta Mayang Kota Jambi sebesar 1,553\%.

f. Koefisien regresi dari dimensi Kompensasi $\left(\mathrm{X}_{5}\right)$.

Koefisien regresi Kompensasi menunjukkan angka positif 0,512 yang berarti dengan penambahan satu satuan dimensi kompensasi akan terjadi peningkatan terhadap kepuasan pelanggan internal pada PDAM Tirta Mayang Kota Jambi sebesar $0,512 \%$.

Berikut ini diuraikan hasil pengujian pengaruh secara parsial untuk masingmasing variabel independen:

a. Kooefisien regresi dari Komunikasi Internal (X1) untuk unstandardized sebesar $-0,047$ dengan nilai $\mathrm{t}$ hitung sebesar $-0,107$ sedangkan $\mathrm{t}$ tabel pada $\alpha=0,05$ adalah sebesar 1,992 dengan nilai signifikan sebesar 0,915. Karena $t_{\text {hitung }}<\mathrm{t}$ tabel maka Ho di terima dan menolak Ha, karena $t$ hitung lebih kecil dari $t$ tabel, berarti tidak menunjukkan pengaruh positif signifikan dari variabel komunikasi internal terhadap kepuasan pelanggan internal, tetapi berpengaruh negatif signifikan maka tidak terbukti bahwa komunikasi internal memberi pengaruh dan signifikan terhadap kepuasan pelanggan internal. Tetapi hanya berpengaruh negatif signifikan.

b. Kooefisien regresi dari Penerimaan Karyawan (X2) untuk unstandardized sebesar 1,231 dengan nilai $t$ hitung sebesar 3,571 sedangkan $t$ tabel pada $\alpha=0,05$ adalah sebesar 1,992 dengan nilai signifikan sebesar 0,001 karena $t_{\text {hitung }}>t$ tabel maka Ho di tolak dan menerima Ha, karena $t$ hitung lebih besar dari $t$ tabel, berarti menunjukkan adanya pengaruh positif signifikan dari variabel penerimaan karyawan terhadap kepuasan pelanggan internal, maka terbukti bahwa penerimaan karyawan memberi pengaruh dan signifikan terhadap kepuasan pelanggan internal.

c. Kooefisien regresi dari training/Pengembangan (X3) untuk unstandardized sebesar -,037 dengan nilai $t_{\text {hitung }}$ sebesar $-0,119$ sedangkan $t$ tabel pada $\alpha=0,05$ adalah sebesar 1,992 dengan nilai signifikan sebesar 0,906, karena $t_{\text {hitung }}<t$ tabel maka Ho di terima dan menolak Ha, karena $t$ hitung lebih kecil dari $t$ tabel, berarti tidak menunjukkan adanya pengaruh positif signifikan dari variabel Training karyawan terhadap kepuasan pelanggan internal, tetapi berpengaruh negative signifikan, maka tidak terbukti bahwa training karyawan memberi pengaruh dan signifikan terhadap kepuasan pelanggan internal. Tetapi hanya berpengaruh negative signifikan.

d. Kooefisien regresi dari Pemberdayaan (X4) untuk unstandardized sebesar 1,553 dengan nilai $t$ hitung sebesar 4,724 sedangkan $t$ tabel pada $\alpha=0,05$ adalah sebesar 1,992 dengan nilai signifikan sebesar 0,000 , karena $t_{\text {hitung }}>t$ tabel maka Ho di tolak dan menerima Ha, karena $t$ hitung lebih besar dari $t$ tabel, berarti menunjukkan adanya pengaruh signifikan dari variabel pemberdayaan karyawan terhadap kepuasan pelanggan internal, maka terbukti bahwa 
pemberdayaan karyawan memberi pengaruh dan signifikan terhadap kepuasan pelanggan internal.

e. Kooefisien regresi dari Kompensasi (X5) untuk unstandardized sebesar 0,512 dengan nilai $\mathrm{t}$ hitung sebesar 1,626 sedangkan $\mathrm{t}$ tabel pada $\alpha=0,05$ adalah sebesar 1,992 dengan nilai signifikan sebesar 0,109, karena $t_{\text {hitung }}<\mathrm{t}$ tabel maka Ho di terima dan menolak $\mathrm{Ha}$, karena $\mathrm{t}$ hitung lebih kecil dari $\mathrm{t}$ tabel, berarti menunjukkan tidak adanya pengaruh positif signifikan dari variabel kompensasi karyawan terhadap kepuasan pelanggan internal, maka tidak terbukti bahwa kompensasi karyawan memberi pengaruh dan signifikan terhadap kepuasan pelanggan internal.

\section{Uji Simultan (Uji F)}

Pengujian pengaruh simultan dilakukan untuk mengetahui apakah variabelvariabel independen yang digunakan model secara simultan mempengaruhi variabel dependen. Untuk menguji pengaruh simultan ini digunakan Uji Anova (uji F).

Tabel 6. Hasil Uji F

\begin{tabular}{lllllll}
\multicolumn{2}{l}{ ANOVA $^{\mathbf{b}}$} \\
\hline \multicolumn{1}{l}{ Model } & Sum of Squares & Df & Mean Square & F & Sig. \\
\hline 1 & Regression & 3410.193 & 5 & 682.039 & 23.246 & $.000^{\mathrm{a}}$ \\
& Residual & 1936.460 & 66 & 29.340 & & \\
& Total & 5346.653 & 71 & & & \\
\hline
\end{tabular}

a. Predictors: (Constant), Kompensasi, Komunikasi, Training, Penerimaan, Pemberdayaan

b. Dependent Variable: KepuasanPelanggan

Nilai $\mathrm{F}$ dan taraf signifikan yang diperoleh pada tabel diatas menyatakan menolak Ho dan menerima Ha dengan alasan nilai $\mathrm{F}$ hitung 23,246 > F tabel (2,35), Serta nilai signifikan 0,000. Sehingga dimensi pemasaran internal secara simultan mempunyai pengaruh positif yang signifikan terhadap kepuasan pelanggan internal perusahaan pada PDAM Tirta Mayang Kota Jambi.Dalam artian setiap perubahan yang terjadi pada variabel independen yang terinci dalam variabel independen secara bersama akan berpengaruh pada perubahan kepuasan pelanggan internal di PDAM Tirta Mayang Kota Jambi.

\section{Simpulan}

\section{SIMPULAN DAN SARAN}

Berdasarkan hasil uji t dapat di ketahui secara individu dari lima dimensi pemasaran internal, terdapat tiga dimensi yang tidak memiliki pengaruh positif signifikan terhadap kepuasan pelanggan internal pada PDAM Tirta Mayang Kota Jambi, yaitu komunikasi internal dan training karyawan serta kompensasi sedangkan untuk variabel penerimaan karyawan dan pemberdayaan mempunyai pengaruh positif yang signifikan.Selain itu setelah di lakukan uji $F$ dapat diketahui bahwa dimensi pemasaran internal memiliki pengaruh signifikan terhadap kepuasan pelanggan internal perusahaan pada PDAM Tirta Mayang Kota Jambi.Pengujian secara simultan atau bersama dapat dijelaskan bahwa pemasaran internal mempengaruhi sebesar 61,00 persen terhadap kepuasan pelanggan internal, dan sisanya terdapat faktor lain yang belum di teliti. 


\section{Saran}

Bertolak dari kesimpulan penelitian, maka peneliti mencoba memberikan masukan atau pertimbangan kepada pemangku jabatan PDAM Tirta Mayang Kota Jambi untuk memperhatikan faktor yang mempengaruhi pemasaran internal dalam rangka meningkatkan kepuasan pelanggan internal perusahaan. Selanjutnya juga disarankan untuk penelitian selanjutnya agar memperluas objek dan variabel penelitian pada perusahaan daerah dan BLU di Kota Jambi, sehingga hasilnya dapat digeneralisasi.

\section{DAFTAR PUSTAKA}

Ahmed P.K. and Rafiq, 2003. "Internal Marekting Issues and Challenges" European Journal Of Marketing 37 (9) 1177-1188.

Berry, L, L and Parshuraman A, 1991. Marketing Service: Competing Through Time, NewcYork: Free Press.

Conduit, J, And Mavondo F. T, 2001. "How Critical Id Internal Customer Orientation To Market Orientation?" Journal Of Bussines Riset 51(1): pp.11-24

Chang. C. S \& Chang HC, 2009. "Perceptions of Internal Marketing and Organizational By. Nurse)". Jurnal Of Advanced Nursing 65 (1) 92-100.

Eldeen, A.T., dan A.T. El-Said,2011. "Implementation ofinternal marketingon a sampleof Egyptianfive-starhotels". Anatolia-AnInternational Journal of Tourism and Hospitality Research. Vol.22 No.2 (August):153-167.

Hung, J. \& Lin, T., 2008. "The Investigation on The Internal Marketing Practices of The International Tourism Hotel Chains". Journal of International Manajement Studies, pp.170-6.

Hertline, M. dan Ferell, 1996. "The Management Of Customer Contact Service Employess An Empirical Investigation” Journal of Marketing Vol. 69 (Oktober) P. 52-70.

Hersh, A.A.S., 2011. "Relationship between internal marketing and service quality with customers' satisfaction”. International Journal of Marketing Studies. Vol.3 No.2.

Kottler, P., 1997. Marketing Management, Eleventh Edition, Prentice-hall, Inc.

Lombard,R.M.,2010. "Employees as customers-An internal marketing study of the Avis carrental group in South Africa". African Journal of Business Management Vol..4 No.4:362-372.

Mishra,S.,2010. 'Internal Marketing-A tool to harness employees' power inervice organizations in India”. International of Business Management. Vol.5 No.1: 185-193.

Ribhan, 2010. "Pengaruh Job satisfaction, organizational commitment terhadap customers satisfaction dengan internal marketing sebagai varaibel mediasi". Lampung (Id) JBM Vol. 6 No. 2.

Robbins, Stephen, P., 2003. Organizational Behaviour $10^{\text {th }}$ edition New Jersey Prentice Hall. Inc.

Rafiq, M and Ahmed P, 1998. "A Customer oriented Framework for Empowering service employees” Journal Of Service Marketing 12(5) pp 397-394. 